\title{
Analysis of Operational Readiness and Reliability of the Paper Machine System after Implementation of Model of Influence
}

\author{
Dejan BRANKOVIĆ, Zdravko MILOVANOVĆ, Stevo BOROJEVIĆ
}

\begin{abstract}
Specific results of effects of investment activities are expressed through effectiveness and reliability of a production process, or business system operations Investment activities are implemented and verified through a certain decision-making matrix - the model of influence. Corrective effect of implementation of investment activities on effectiveness of real industrial system is shown by the research of operational readiness and reliability of the paper machine real system. Positive movements resulting from the raising of overall efficiency of industrial plant which are expressed by the change of operational readiness and reliability, and thus by higher performance per hour, are the confirmation and justification of investments in new technical solutions. Operational readiness and reliability of a real industrial system are analysed for two equal monitoring periods immediately before and after implementation of corrective measures i.e. investment activities, i.e. from the term of general overhaul of the paper machine.
\end{abstract}

Keywords: efficiency; investment activity; maintenance; model of influence; operative readiness; reliability

\section{INTRODUCTION}

Production, as a basic element of profit making, is an activity that has to be acted on positively. The conditions for the smooth functioning of production have to be created as well as the conditions for its growth. The growth of production provides the creation of positive economic developments enabling the development of business systems as well as of the society as a whole. Maintenance, unscheduled downtime, and energy costs are three of the highest budget items for any facility [1].

One of the ways of active work on production is the investment activity. Specific results of investment activities are represented through effectiveness and reliability of the production process, i.e. business operations of the business system. Correct evaluation of reliability for the system or components is very important for high quality and security [2].

The research within this paper includes the influence of production investment on its effectiveness through the effects of maintenance.

Theoretical and scientific implications are connected with very good and simple research of effectiveness of industrial system as well as the reliability of operative readiness. The system is analysed in the condition before and after the realization of key investment activities, which provides its full verification by measurable parameters.

There are many papers published in the field of analysis of the maintenance, effectiveness and reliability of production systems as well as the selection of strategy of investing in production processes.

The efficacy of application of the combination of Markov chains and systematic-dynamic modelling during research on technical systems reliability problem is elaborated in [3]. By the application of systematicdynamic simulation model it is possible to quantify the system structure maintenance efficacy parameters and enable better reliability and availability of a specific technical system.

The analysis of the importance of investment in the working process in relation to the performance of maintaining was given in [4]. An example of adequate maintenance strategy is presented through the organization of technical system of thermal power plant.

Maintenance of the power generating facilities in due time is essential for reliable and secure operation of the electric power system. The paper [5] addresses the problem of obtaining the optimal maintenance schedule of hydro generating units. For this purpose, the paper discusses the mathematical programming method Benders decomposition.

The analysis of parameters of efficiency of production systems is presented in a systematic and transparent manner in [6]. Relevant data describing the performance of a system can be obtained by calculating operational readiness and reliability. The efficiency is presented as a characteristic of the production system, but it is also to the same extent the aim and measure of the success of production system maintenance.

The cost analysis of reliability for all stages of life cycle with an emphasis on the design and development stage, the production stage and the exploitation stage is shown in [7]. The paper appropriately explains a very important issue for all industrial plants and technical systems in general, and the costs in their life cycle.

The reliability tests on the example of thermal plant Nikola Tesla B are presented in [8]. The reliability is analysed as a function of the probability that the observed system will perform certain function of the objective. Special emphasis is given to the analysis of cross section of curves reliability and unreliability. The parameters of analytical verification of the proposed model for the assessment of optimal reliability were tested by applying the graphical method of assessment of distribution parameters - paper of probability [9].

\section{IMPLEMENTATION OF INVESTMENT ACTIVITIES \\ 2.1 Application of the model of influence}

Critical spots leading to a significant number of system downtimes were identified by creating a database of the history of downtimes of paper machine. The specific problems were solved by applying the Model of influence of implementation of investment activities. The Structure of Model of influence is shown in Fig. 1. 


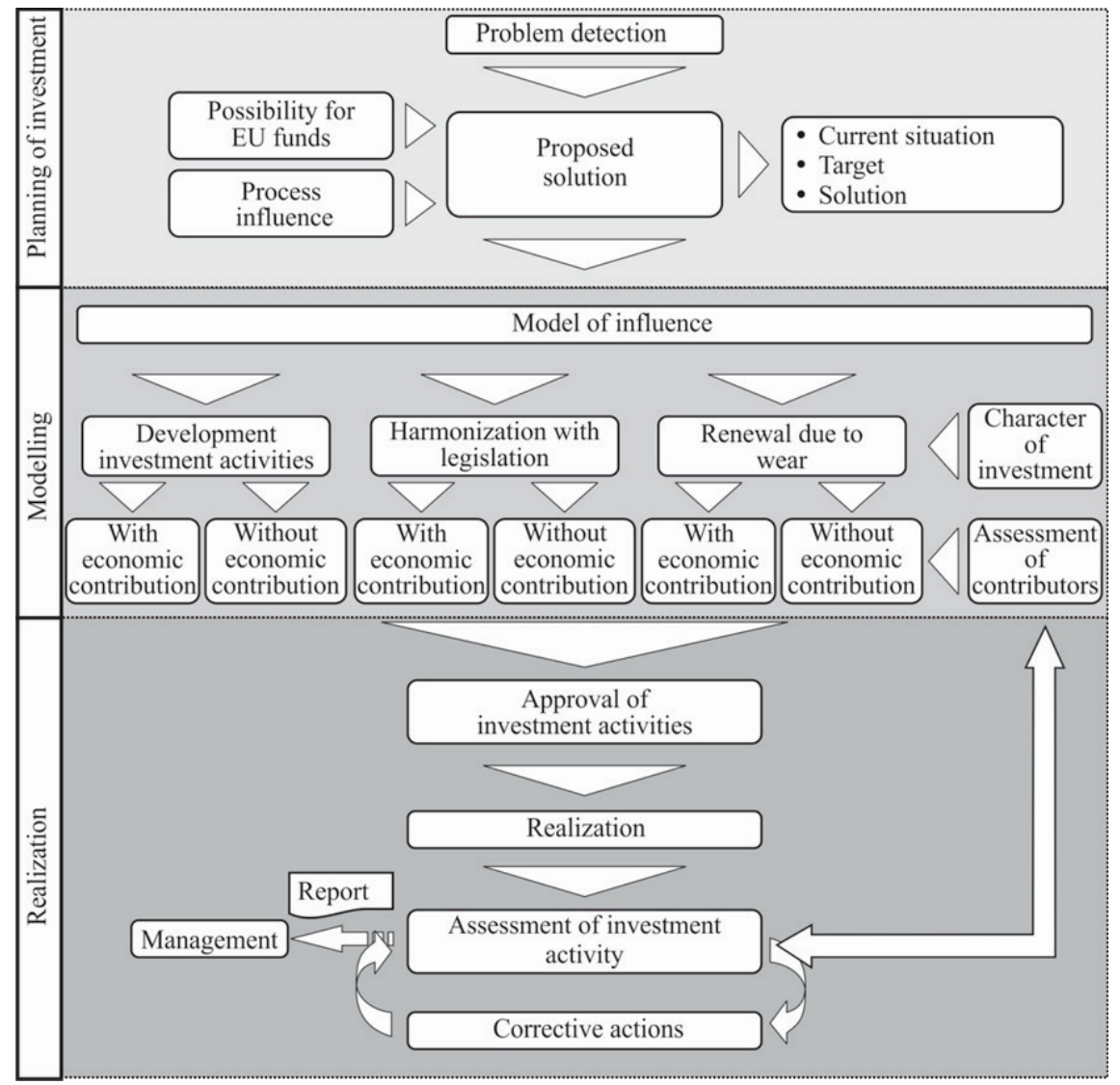

Figure 1 Model of influence of investment activities

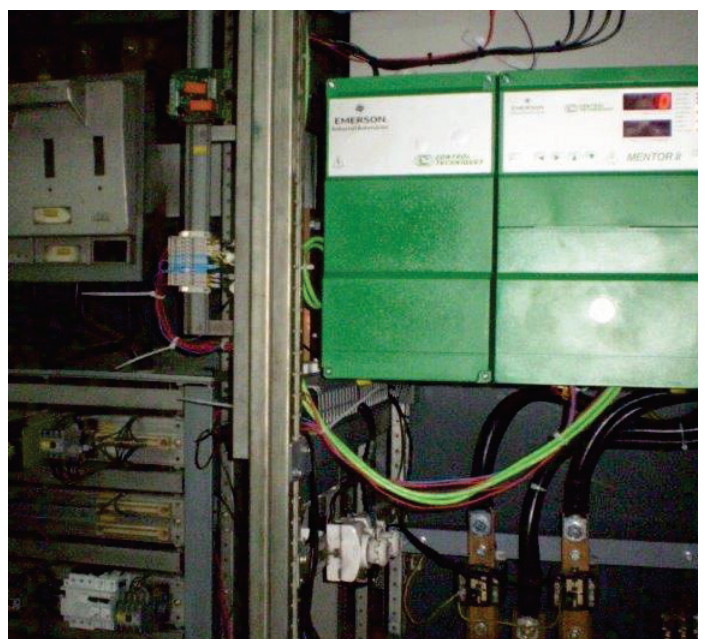

Figure $2 \mathrm{DC}$ drive regulator

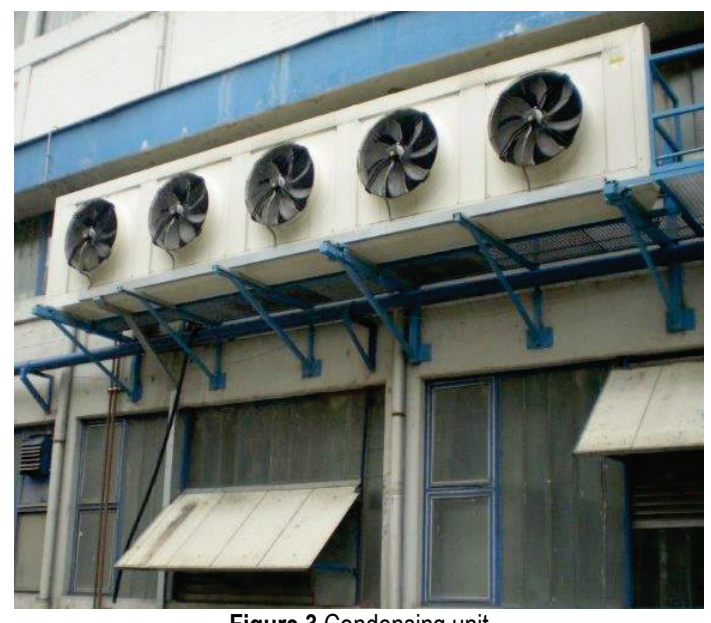

Figure 3 Condensing unit

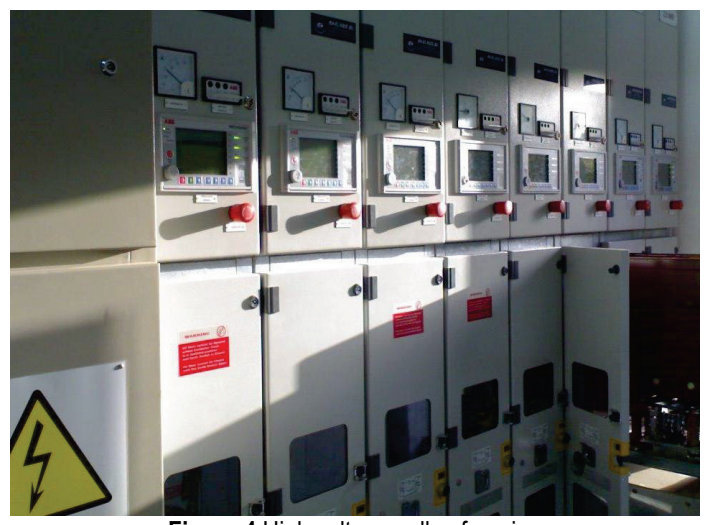

Figure 4 High voltage cells of engine

\subsection{Verification of the Model of Influence}

The observed real system, i.e. the international company SHP Celex, a.d. Banja Luka has been analysed since 2003. Keeping of records of downtime and defining of nature of the failures were included in the analysis. Certain critical spots that cause downtime of paper machine can be identified on the basis of the records of downtime.

The results of technical solutions for recorded problems:

- Replacement of old analogue controller with the new digital controller produced by "Control Techniques", United Kingdom on DC motors of paper machine, as shown in Fig. 2.

- System for increase of the cooling capacity of lowvoltage room and control room of paper machines, as shown in Fig. 3. 
- Design, delivery and assembly of high-voltage cells, as shown in Fig. 4.

\section{ANALYSIS OF OPERATIONAL READINESS AND RELIABILITY OF THE REAL SYSTEM}

\subsection{Analysis of Operational Readiness}

Readiness $(G)$ of the production system is defined as a probability that the real system successfully operates at any given point in time under real environmental conditions. The readiness of the real system is calculated by the following mathematical relation:

$$
G(t)=\frac{\overline{t_{i}}}{\overline{t_{i}}-\bar{t}_{o}},
$$

where is: $\overline{t_{i}}$ - mean time of the system in good working order; $\bar{t}_{o}$ - mean time of the system in failure.

Readiness is exponential function of the time of operation and time of failure, and it may be expressed as follows:

$G(t)=\frac{\mu}{\lambda+\mu}+\frac{\lambda}{\lambda+\mu} \cdot \mathrm{e}^{-(\lambda+\mu) \cdot t}$

where is: $\mu=\frac{1}{\overline{t_{o}}}$ - intensity of operation; $\lambda=\frac{1}{\overline{t_{i}}}$ intensity of failure.
If we calculate limit of a function $G(t)$ the result is the coefficient of readiness $k_{G}$, i.e.:

$k_{G} \lim G(t)=\frac{\mu}{\lambda+\mu}=\frac{\overline{t_{i}}}{\overline{t_{i}}+\bar{t}_{o}}=k_{O G}$

When we get the operational readiness $(O G)$ as a function of time when the system is in operation and in failure:

$O G(t)=\lim G(t)=\frac{\overline{t_{r}}}{\overline{t_{r}}+\bar{t}_{o}}=k_{O G}$

where is: $\overline{t_{r}}$ - time of the system in operation; $\bar{t}_{o}$ - time of the system in failure.

The condition of the real system was analysed for the period before the time of implementation of investment activities and $k_{O G}$ at that moment as well as $k_{O G}$ in the period after the implementation of the aforementioned activities.

\subsubsection{Operative Readiness to the Moment of General Overhaul}

Analysis of $k_{O G}$ before the implementation of activities is shown in Tab. 1 and graphically presented in Fig. 5. If we analyse the given Graph we can notice the tendency of fall of the curve of operational readiness coefficient, which indicates certain trend of the decrease in efficiently of the plant in real system.

Table 1 Operational readiness coefficient to the moment of implementation of investment activities

\begin{tabular}{|c|c|c|c|c|c|c|c|}
\hline & Month & $\begin{array}{c}\text { Total availability } \\
\text { (hours) }\end{array}$ & $\begin{array}{c}t_{r i}-\text { time of the } \\
\text { system in operation } \\
\text { (hours) }\end{array}$ & $\begin{array}{c}t_{o i}-\text { time of the } \\
\text { system in failure } \\
\text { (hours) }\end{array}$ & $t_{r i}+t_{o i}$ & $\begin{array}{c}k_{O G}(t) \text { operational } \\
\text { readiness } \\
\text { coefficient }\end{array}$ & $\begin{array}{c}\text { Number } \\
\text { of } \\
\text { failures }\end{array}$ \\
\hline \multirow{12}{*}{2011} & \begin{tabular}{|l|} 
January \\
\end{tabular} & 744 & 664 & 14,5 & 678,5 & 0,978629329 & 12 \\
\hline & \begin{tabular}{|l|} 
February \\
\end{tabular} & 672 & 620 & 22,5 & 642,5 & 0,964980545 & 7 \\
\hline & March & 744 & 672 & 32 & 704 & 0,954545455 & 11 \\
\hline & April & 720 & 666 & 9,25 & 675,25 & 0,98630137 & 5 \\
\hline & May & 744 & 667 & 8,3 & 675,3 & 0,987709166 & 7 \\
\hline & June & 720 & 622 & 32,2 & 654,2 & 0,950779578 & 12 \\
\hline & July & 744 & 680 & 36,2 & 716,2 & 0,949455459 & 13 \\
\hline & August & 744 & 668 & 36 & 704 & 0,948863636 & 14 \\
\hline & September & 720 & 685 & 9,5 & 694,5 & 0,986321094 & 9 \\
\hline & October & 744 & 661 & 41,5 & 702,5 & 0,940925267 & 6 \\
\hline & November & 720 & 673 & 7 & 680 & 0,989705882 & 3 \\
\hline & December & 744 & 674 & 25 & 699 & 0,964234621 & 15 \\
\hline \multirow{4}{*}{2012} & January & 744 & 622 & 45,5 & 667,5 & 0,931835206 & 9 \\
\hline & February & 672 & 598 & 46,2 & 644,2 & 0,928283142 & 13 \\
\hline & March & 744 & 686 & 19,5 & 705,5 & 0,972360028 & 14 \\
\hline & April & 720 & 512 & 18,7 & 530,7 & 0,96476352 & 6 \\
\hline & Total: & 11640 & 10370 & 403,85 & 10773,85 & 0,962480831 & 156 \\
\hline
\end{tabular}

\subsubsection{Operational Readiness after the Term of General Overhaul}

Analysis of $k_{O G}$ after the implementation of investment activities is shown in Tab. 2 and graphically presented in Fig. 6. The growth and accordingly the increase of the efficiency of the real system plant can be seen by analysing the obtained Graph.

\subsection{Analysis of the Real System Reliability}

Analysis and research of reliability defines the behaviour of the system and maintenance of operating characteristics under the influence of various factors causing changes of the system. The observed factors are directly related to the work of the maintenance service.

Reliability is the probability of retaining the required performance of the system in real-time exploitation with 
all limiting factors appearing in the given interval. Reliability can be clearly and unambiguously quantified only after recording the conditions of system failures. The goal is to predict the moment of failure based on previously collected data.

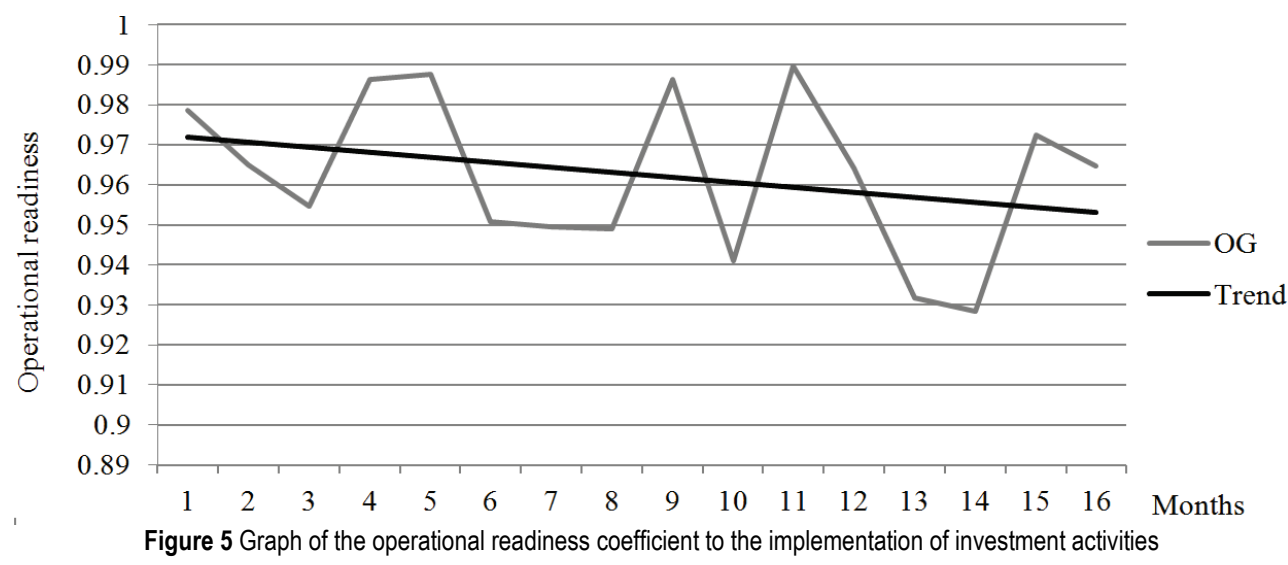

Table 2 Operational readiness coefficient after the implementation of investment activities

\begin{tabular}{|c|c|c|c|c|c|c|c|}
\hline \multicolumn{2}{|r|}{ Month } & $\begin{array}{c}\text { Total } \\
\text { availability } \\
\text { (hours) }\end{array}$ & $\begin{array}{c}t_{r i} \\
\text { time of the system in } \\
\text { operation (hours) }\end{array}$ & $\begin{array}{c}t_{o i} \\
\text { time of the system in } \\
\text { failure (hours) }\end{array}$ & $t_{r i}+t_{o i}$ & $\begin{array}{c}k_{O G}(t) \\
\text { operational } \\
\text { readiness coefficient }\end{array}$ & $\begin{array}{c}\text { Number of } \\
\text { failures }\end{array}$ \\
\hline \multirow{8}{*}{2012} & May & 744 & 659 & 22,5 & 681,5 & 0,966984593 & 21 \\
\hline & June & 720 & 654 & 16,2 & 670,2 & 0,975828111 & 19 \\
\hline & July & 744 & 668 & 27,5 & 695,5 & 0,960460101 & 11 \\
\hline & August & 744 & 660 & 35,75 & 695,75 & 0,948616601 & 14 \\
\hline & September & 720 & 663 & 13,7 & 676,7 & 0,979754692 & 10 \\
\hline & October & 744 & 666 & 14,5 & 680,5 & 0,978692138 & 10 \\
\hline & November & 720 & 669 & 7,7 & 676,7 & 0,98862125 & 11 \\
\hline & December & 744 & 709 & 5 & 714 & 0,992997199 & 8 \\
\hline \multirow{8}{*}{2013} & January & 744 & 685 & 8,7 & 693,7 & 0,987458556 & 8 \\
\hline & February & 696 & 635 & 7,5 & 642,5 & 0,988326848 & 5 \\
\hline & March & 744 & 688 & 11,25 & 699,25 & 0,983911334 & 12 \\
\hline & April & 720 & 675 & 6 & 681 & 0,991189427 & 7 \\
\hline & May & 744 & 680 & 23 & 703 & 0,967283073 & 9 \\
\hline & June & 720 & 663 & 15,5 & 678,5 & 0,97715549 & 11 \\
\hline & July & 744 & 707 & 3,5 & 710,5 & 0,995073892 & 5 \\
\hline & August & 744 & 707 & 1,5 & 708,5 & 0,997882851 & 3 \\
\hline & Total: & 11736 & 10788 & 219,8 & 11007,8 & 0,98001476 & 164 \\
\hline
\end{tabular}

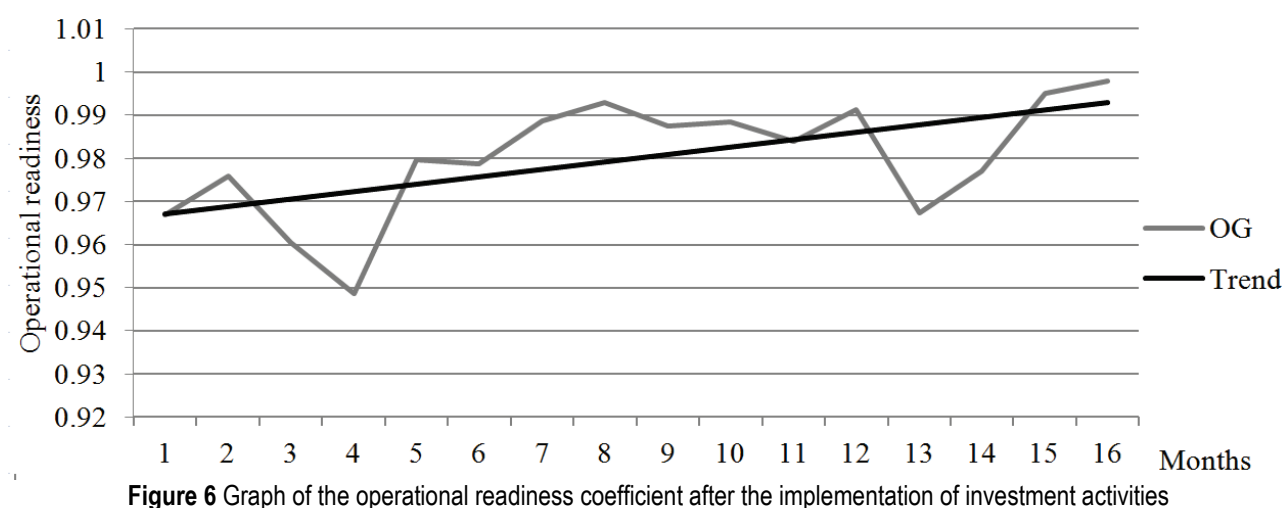

\subsubsection{Analysis of the General Overhaul Reliability}

Calculation of elements of reliability is based on the analysis of time of operation of paper machine taking into account the following information:

- time of operation of the real system,

- number of hours of downtime caused by maintenance,

- number of hours of operation to the occurrence of failure.
The results of the analysis are collectively presented in Tab. 3.

The analysis of reliability consists of:

- $\quad$ setting of hypothesis of the law of distribution

- checking of suitability of the set analysis

- $\quad$ setting of parameters of the law of distribution

- presentation of diagram - density function of the time of operation to the failure. 
Table 3 Reliability to the moment of implementation of investment activities

Production on the paper machine January 2011 - April 2012

\begin{tabular}{|c|c|c|c|c|c|c|c|}
\hline \multicolumn{8}{|c|}{$\begin{array}{l}\text { Production on the paper machine January } 2011-\text { April } 2012 \\
\text { (Period to the general overhaul aimed at increasing the effectiveness of the paper machine) }\end{array}$} \\
\hline & Month & $\begin{array}{l}\text { Total availability } \\
\text { (hours) }\end{array}$ & $\begin{array}{c}\text { Planned } \\
\text { maintenance } \\
\text { downtimes } \\
\text { (hours) }\end{array}$ & $\begin{array}{c}\text { Degree of use - } \\
\text { total working } \\
\text { hours } \\
\text { (hours) }\end{array}$ & $\begin{array}{l}\text { Downtimes caused by } \\
\text { maintenance (hours) }\end{array}$ & $\begin{array}{l}\text { Production } \\
\text { output (tons) }\end{array}$ & Waste (tons) \\
\hline \multirow{12}{*}{2011} & January & 744 & 4 & 664 & 14,5 & 2947,8 & 260 \\
\hline & February & 672 & 4 & 620 & 22,5 & 2748,7 & 232 \\
\hline & March & 744 & 4 & 672 & 32 & 2783,9 & 185 \\
\hline & April & 720 & 4 & 666 & 9,25 & 2702,1 & 152 \\
\hline & May & 744 & 4 & 667 & 8,3 & 2769,6 & 249 \\
\hline & June & 720 & 4 & 622 & 32,2 & 2759,9 & 143 \\
\hline & July & 744 & 4 & 680 & 36,2 & 3239,6 & 211 \\
\hline & August & 744 & 124 & 668 & 36 & 3197 & 271 \\
\hline & September & 720 & 4 & 685 & 9,5 & 3435,5 & 267 \\
\hline & October & 744 & 4 & 661 & 41,5 & 3167,2 & 339 \\
\hline & November & 720 & 4 & 673 & 7 & 3352,7 & 286 \\
\hline & December & 744 & 4 & 674 & 25 & 3206,2 & 270 \\
\hline \multirow{4}{*}{2012} & January & 744 & 18 & 622 & 45,5 & 2507,4 & 188 \\
\hline & February & 672 & 18 & 598 & 46,2 & 2679,5 & 193 \\
\hline & March & 744 & 18 & 686 & 19,5 & 3313,1 & 196 \\
\hline & April & 720 & 128 & 512 & 18,7 & 2455,5 & 175 \\
\hline & Total: & 11640 & 350 & 10370 & 403,85 & 47265,7 & 3617 \\
\hline
\end{tabular}

Table 4 Concept of graphical determination of parameters of Weibull distribution for the interval before the general overhaul

\begin{tabular}{|c|c|c|c|c|c|}
\hline $\begin{array}{c}\text { Months } \\
n_{i}\end{array}$ & $\begin{array}{l}\text { Interval } \\
\text { hours (h) }\end{array}$ & $\begin{array}{c}\text { Mean of the } \\
\text { interval } \\
\text { hours (h) }\end{array}$ & $\begin{array}{c}t_{i} \\
\text { number of } \\
\text { hours of } \\
\text { operation }\end{array}$ & $\begin{array}{l}\text { Cumulative number of } \\
\text { hours of operation }\end{array}$ & $\begin{array}{l}\text { Cumulative probability } \\
\qquad F(t)\end{array}$ \\
\hline 1 & $0 \div 744$ & 372 & 45,79 & 45,79 & 0,076 \\
\hline 2 & $744 \div 1416$ & 1080 & 27,56 & 73,35 & 0,122 \\
\hline 3 & $1416 \div 2160$ & 1788 & 21,00 & 94,35 & 0,157 \\
\hline 4 & $2160 \div 2880$ & 2520 & 72,00 & 166,35 & 0,276 \\
\hline 5 & $2880 \div 3624$ & 3252 & 80.36 & 246,71 & 0,409 \\
\hline 6 & $3624 \div 4344$ & 3984 & 19,32 & 266,03 & 0,44 \\
\hline 7 & $4344 \div 5088$ & 4716 & 18,78 & 284,81 & 0,472 \\
\hline 8 & $5088 \div 5832$ & 5460 & 18,56 & 303,37 & 0,503 \\
\hline 9 & $5832 \div 6552$ & 6192 & 72,11 & 375,48 & 0,622 \\
\hline 10 & $6552 \div 7272$ & 6912 & 15,93 & 391,41 & 0,648 \\
\hline 11 & $7272 \div 7992$ & 7632 & 96,14 & 487,55 & 0,807 \\
\hline 12 & $7992 \div 8732$ & 8362 & 26,96 & 514,51 & 0,852 \\
\hline 13 & $8732 \div 9476$ & 9104 & 13,67 & 528,18 & 0,875 \\
\hline 14 & $9476 \div 10148$ & 9812 & 12,94 & 541,12 & 0,896 \\
\hline 15 & $10148 \div 10892$ & 10520 & 35,18 & 576,3 & 0,955 \\
\hline 16 & $10892 \div 11612$ & 11252 & 27,38 & 603,68 & 1 \\
\hline
\end{tabular}

Analyses/testing of hypotheses about the laws of distribution have shown that the time of operation of the equipment to the occurrence of failure does not correspond to the normal or exponential distribution. For this reason, the assumption that the time of operation of equipment to the occurrence of failure corresponds to the Weibull distribution has been introduced.

Weibull distribution density function of:

$$
f(t)=\frac{\beta}{\eta} \cdot\left(\frac{t-\gamma}{\eta}\right)^{\beta-1} \cdot \mathrm{e}^{-\left(\frac{t-\gamma}{\eta}\right)}
$$

Where: $f(t) \geq 0, t \geq \gamma$ - distribution density, $\beta>0$ - shape parameter, $\eta>0-$ scale parameter, $-\infty<\gamma<+\infty-$ location parameter for three-parameter distributions.

Where: $f(t)=\lambda(t) \cdot R(t)$ the following values can be seen:

$\lambda(t)=\frac{\beta}{\eta} \cdot\left(\frac{t-\gamma}{\eta}\right)^{\beta-1}-$ failure intensity

$R(t)=\mathrm{e}^{-\left(\frac{t-\gamma}{\eta}\right)^{\beta}}-$ reliability

In case of two-parameter distribution cumulative function of Weibull distribution is:

$F(t)=1-R(t)=1-\mathrm{e}^{-\left(\frac{t}{\eta}\right)^{\beta}}$

Where $F(t)$ - unreliability function.

Parameters of Weibull distribution are analytically determined according to Tabs. 4 and 5. 
Parameters of the Weibull model are:

$\beta=\frac{\sum X_{i} \cdot Y_{i}-\frac{1}{n} \sum Y_{i} \cdot \sum X_{i}}{\sum X_{i}^{2}-\frac{1}{n} \sum X_{i} \cdot \sum X_{i}}=1,27$

$\eta=\exp \left[-\frac{\frac{1}{n}\left(\sum Y_{i}-\beta \cdot \sum X_{i}\right)}{\beta}\right]=1311,172$

According to Tab. 6 maximum difference $D_{\max }=$ 0,115 while $D C R=0,328$ according to table values [9] for $\mathrm{K}-\mathrm{S}$ test for 16 measurements and significance factor 0,05 .

Where: $D_{\max }>D_{C R}$

are parameters of real system corresponding to Weibull distribution.

Diagram of probability of Weibull distribution for the period to the general overhaul is shown in Fig. 7. Fig. 8 presents graphical interpretation of reliability/unreliability functions.

Table 5 Tabular concept of analytical determination of parameters for interval to the general overhaul

\begin{tabular}{|c|c|c|c|c|}
\hline $\begin{array}{c}\text { Months } \\
n_{i}\end{array}$ & $\begin{array}{c}X_{i}= \\
\ln (t)\end{array}$ & $\begin{array}{c}Y_{i}=\ln \ln \\
1 /(1-F(t))\end{array}$ & $X_{i}^{2}$ & $X_{i}-Y_{i}$ \\
\hline 1 & 5,918 & $-2,537$ & 35,022724 & $-15,013966$ \\
\hline 2 & 6,984 & $-2,039$ & 48,776256 & $-14,240376$ \\
\hline 3 & 7,488 & $-1,767$ & 56,070144 & $-13,231296$ \\
\hline 4 & 7,832 & $-1,130$ & 61,340224 & $-8,85016$ \\
\hline 5 & 8,087 & $-0,642$ & 65,399569 & $-5,191854$ \\
\hline 6 & 8,290 & $-0,545$ & 68,7241 & $-4,51805$ \\
\hline 7 & 8,458 & $-0,448$ & 71,537764 & $-3,789184$ \\
\hline 8 & 8,605 & $-0,357$ & 74,046025 & $-3,071985$ \\
\hline 9 & 8,731 & $-0,027$ & 76,230361 & $-0,235737$ \\
\hline 10 & 8,841 & 0,043 & 78,163281 & 0,380163 \\
\hline 11 & 8,940 & 0,497 & 79,9236 & 4,44318 \\
\hline 12 & 9,031 & 0,647 & 81,558961 & 5,843057 \\
\hline 13 & 9,116 & 0,732 & 83,101456 & 6,672912 \\
\hline 14 & 9,191 & 0,816 & 84,474481 & 7,499856 \\
\hline 15 & 9,261 & 1,131 & 85,766121 & 10,474191 \\
\hline 16 & 9,328 & 1 & & \\
\hline & & & & \\
\hline
\end{tabular}

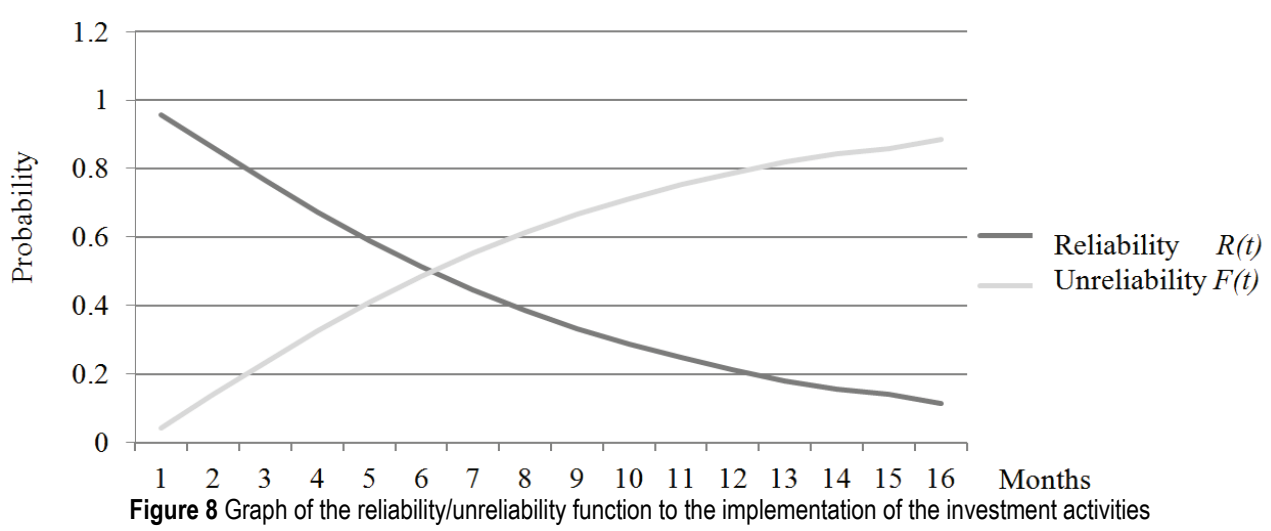




\subsubsection{Analysis of Reliability after the Term of General Overhaul}

Results of the analysis of work of real system and the hours of downtime caused by maintenance are presented collectively in Tab. 8 .

As in the previous case, the task comes down to the setting of assumption about the law of distribution, the checking of suitability of the set hypotheses and the determination of parameters of the law of distribution.
Analysis/testing of hypotheses about the laws of distribution has shown that operation of equipment to the occurrence of failure does not correspond to the normal or exponential distribution. For this reason, the assumption that the operation of the equipment to the occurrence of failure corresponds to Weibull distribution has been introduced. On the basis of (1), for the period after the term of the general overhaul, the Weibull distribution parameters are set according to Tabs. 9 and 10 .

\begin{tabular}{|c|c|c|c|c|c|c|}
\hline & Month & $\begin{array}{l}\text { Total availability } \\
\text { (hours) }\end{array}$ & $\begin{array}{c}\text { Planned hours of } \\
\text { maintenance } \\
\text { downtimes }\end{array}$ & $\begin{array}{c}\text { Achieved hours of } \\
\text { operation of } \\
\text { equipment }\end{array}$ & $\begin{array}{l}\text { Downtimes } \\
\quad \text { (sati) }\end{array}$ & $\begin{array}{c}\text { Hours of } \\
\text { operation to the } \\
\text { occurrence of } \\
\text { failure }\end{array}$ \\
\hline \multirow{8}{*}{2013} & May & 744 & 18 & 659 & 22,5 & 29,29 \\
\hline & June & 720 & 18 & 654 & 16,2 & 40,37 \\
\hline & July & 744 & 18 & 668 & 27,5 & 24,29 \\
\hline & August & 744 & 18 & 660 & 35,75 & 18,46 \\
\hline & September & 720 & 18 & 663 & 13,7 & 48,39 \\
\hline & October & 744 & 18 & 666 & 14,5 & 45,93 \\
\hline & November & 720 & 8 & 669 & 7,7 & 86,88 \\
\hline & December & 744 & 18 & 709 & 5 & 141,80 \\
\hline \multirow{9}{*}{2014} & January & 744 & 23 & 685 & 8,7 & 78,74 \\
\hline & February & 696 & 23 & 635 & 7,5 & 84,67 \\
\hline & March & 744 & 23 & 688 & 11,25 & 61,16 \\
\hline & April & 720 & 23 & 675 & 6 & 112,50 \\
\hline & May & 744 & 23 & 680 & 23 & 29,57 \\
\hline & June & 720 & 23 & 663 & 15,5 & 42,77 \\
\hline & July & 744 & 23 & 707 & 3,5 & 202,00 \\
\hline & August & 744 & 37 & 707 & 1,5 & 471,33 \\
\hline & Total: & 11736 & 332 & 10788 & 219,8 & 49,08 \\
\hline
\end{tabular}

\begin{tabular}{|c|c|c|c|c|}
\multicolumn{7}{c|}{ Table 9 Numerical values of indicators of reliability of exponential distribution after realization of investment activities } \\
\hline $\begin{array}{c}\text { Months } \\
n_{i}\end{array}$ & $t_{i}-$ downtime & $F_{E}\left(t_{i}\right)=n_{i} / n$ & $F_{E}\left(t_{i}\right)=\lambda \cdot \mathrm{e}^{-(\lambda) t_{i}}$ & $D_{i}=\left|F_{o}-F_{E}\right|$ \\
\hline 1 & 29,29 & 0,0625 & 0,01996 & 0,04254 \\
\hline 2 & 40,37 & 0,125 & 0,01956 & 0,10544 \\
\hline 3 & 24,29 & 0,1875 & 0,01916 & 0,16834 \\
\hline 4 & 18,46 & 0,25 & 0,01878 & 0,23122 \\
\hline 5 & 48,39 & 0,3125 & 0,0184 & 0,2941 \\
\hline 6 & 45,93 & 0,375 & 0,01803 & 0,35697 \\
\hline 7 & 86,88 & 0,4375 & 0,01766 & 0,41984 \\
\hline 8 & 141,8 & 0,5 & 0,01731 & 0,48269 \\
\hline 9 & 78,74 & 0,5625 & 0,01696 & 0,54554 \\
\hline 10 & 84,67 & 0,625 & 0,01661 & 0,60839 \\
\hline 11 & 61,16 & 0,6875 & 0,01628 & 0,67122 \\
\hline 12 & 112,5 & 0,75 & 0,01595 & 0,73405 \\
\hline 13 & 29,57 & 0,8125 & 0,01563 & 0,79687 \\
\hline 14 & 42,77 & 0,875 & 0,01531 & 0,85969 \\
\hline 15 & 202 & 0,9375 & 0,015 & 0,9225 \\
\hline 16 & 471,33 & 1 & 0,0147 & 0,9853 \\
\hline
\end{tabular}

Parameters of Weibull model are:

$$
\begin{gathered}
\beta=\frac{\sum X_{i} \cdot Y_{i}-\frac{1}{n} \sum Y_{i} \cdot \sum X_{i}}{\sum X_{i}^{2}-\frac{1}{n} \sum X_{i} \cdot \sum X_{i}}=1,27 \\
\eta=\exp \left[-\frac{\frac{1}{n}\left(\sum Y_{i}-\beta \cdot \sum X_{i}\right)}{\beta}\right]=1311,172
\end{gathered}
$$

According to the following Tab. 11, maximum difference $D_{\max }=0,1543$ while $D C R=0,328$ according to table values [9] for K-S test for 16 measurements and significance factor 0,05 .

Initial hypothesis should be accepted, i.e. the analysed parameters of the real system correspond to Weibull distribution.

Diagram of probability of Weibull distribution for the period after the general overhaul is shown in Fig. 9. The analysis of the mentioned data is presented in Tab. 12 and Fig 10. 
Table 10 Tabular concept of analytical determination of parameters for the interval after the general overhaul

\begin{tabular}{|c|c|c|c|c|}
\hline $\begin{array}{c}\text { Months } \\
n_{i}\end{array}$ & $X_{i}=\ln (t)$ & $Y_{i}=\ln \ln 1 /(1-F(t))$ & $X_{i}^{2}$ & $X_{i}-Y_{i}$ \\
\hline 1 & 5,918 & $-3,953$ & 35,022724 & $-23,393834$ \\
\hline 2 & 7,006 & $-3,078$ & 49,084036 & $-21,564468$ \\
\hline 3 & 7,515 & $-2,765$ & 56,475225 & $-20,778975$ \\
\hline 4 & 7,855 & $-2,565$ & 61,701025 & $-20,148075$ \\
\hline 5 & 8,105 & $-2,198$ & 65,691025 & $-17,81479$ \\
\hline 6 & 8,304 & $-1,922$ & 68,956416 & $-15,960288$ \\
\hline 7 & 8,471 & $-1,539$ & 71,757841 & $-13,036869$ \\
\hline 8 & 8,613 & $-1,088$ & 74,183769 & $-9,370944$ \\
\hline 9 & 8,740 & $-0,885$ & 76,3876 & $-7,7349$ \\
\hline 10 & 8,849 & $-0,691$ & 78,304801 & $-6,114659$ \\
\hline 11 & 8,947 & $-0,563$ & 80,048809 & $-5,037161$ \\
\hline 12 & 9,038 & $-0,343$ & 81,685444 & $-3,100034$ \\
\hline 13 & 9,122 & $-0,286$ & 83,210884 & $-2,608892$ \\
\hline 14 & 9,199 & $-0,208$ & 84,621601 & $-1,913392$ \\
\hline 15 & 9,270 & 0,155 & 85,9329 & 1,43685 \\
\hline 16 & 9,338 & 1 & & \\
\hline
\end{tabular}

Table 11 Kolmogorov- Smirnov test for the period after general repair

\begin{tabular}{|c|c|c|c|}
\hline $\begin{array}{c}\text { Months } \\
n_{i}\end{array}$ & $F_{e}(t)$ & $\begin{array}{c}F_{e}(t)= \\
1-\mathrm{e}^{-(t / 13111,72)^{1,27}}\end{array}$ & $\left|F_{e}(t)-F_{t}(t)\right|$ \\
\hline 1 & 0,019 & 0,0107 & 0,0083 \\
\hline 2 & 0,045 & 0,0422 & 0,0028 \\
\hline 3 & 0,061 & 0,0790 & 0,018 \\
\hline 4 & 0,074 & 0,1191 & 0,0451 \\
\hline 5 & 0,105 & 0,1598 & 0,0548 \\
\hline 6 & 0,136 & 0,2010 & 0,065 \\
\hline 7 & 0,193 & 0,2421 & 0,0491 \\
\hline 8 & 0,286 & 0,2827 & 0,0033 \\
\hline 9 & 0,338 & 0,3232 & 0,0148 \\
\hline 10 & 0,394 & 0,3613 & 0,0327 \\
\hline 11 & 0,434 & 0,3982 & 0,0358 \\
\hline 12 & 0,508 & 0,4345 & 0,0735 \\
\hline 13 & 0,528 & 0,5305 & 0,0025 \\
\hline 14 & 0,556 & 0,5028 & 0,0532 \\
\hline 15 & 0,689 & 0,5347 & 0,1543 \\
\hline
\end{tabular}

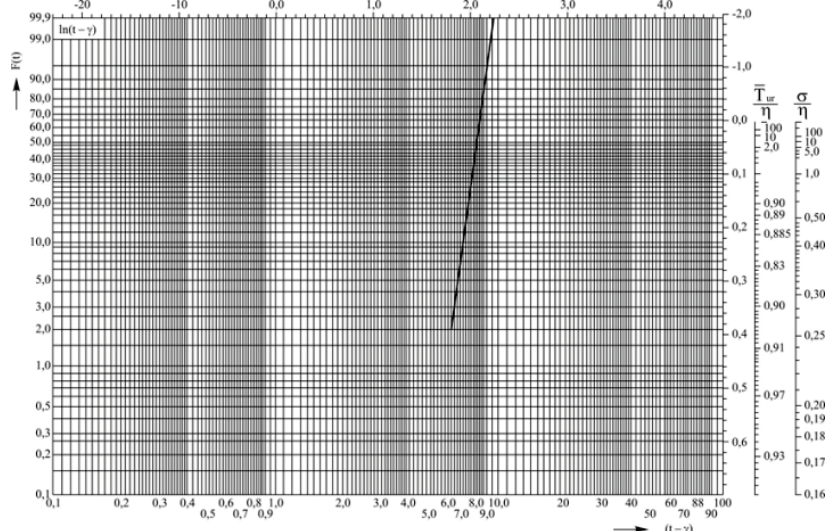

Figure 9 Diagram of probability of Weibull distribution after the general overhaul

Table 12 Statistical values of reliability for the period after implementation of

\begin{tabular}{|c|l|c|c|c|}
\hline \multirow{2}{*}{} & Distribution & $\begin{array}{c}\text { Distribution } \\
\text { parameters }\end{array}$ & $\begin{array}{c}\text { Komogorov- } \\
\text { Smirnovljev } \\
\text { test } D_{\max }\end{array}$ & Note \\
\cline { 2 - 5 } $\begin{array}{c}\text { After } \\
\text { the } \\
\text { general } \\
\text { overhaul }\end{array}$ & Normal & $\begin{array}{c}S V=49,08 \\
S D=117,38\end{array}$ & 2,597 & $\begin{array}{c}\text { It is not } \\
\text { accepted }\end{array}$ \\
\cline { 2 - 6 } & Exponential & $\begin{array}{c}S V=49,08 \\
\lambda=0,02038\end{array}$ & $-0,02$ & $\begin{array}{c}\text { It is not } \\
\text { accepted }\end{array}$ \\
\cline { 2 - 6 } & Weibull & $\begin{array}{c}B=1,27 \\
\eta=13111,72\end{array}$ & 0,1543 & $\begin{array}{c}\text { It can be } \\
\text { accepted }\end{array}$ \\
\hline
\end{tabular}

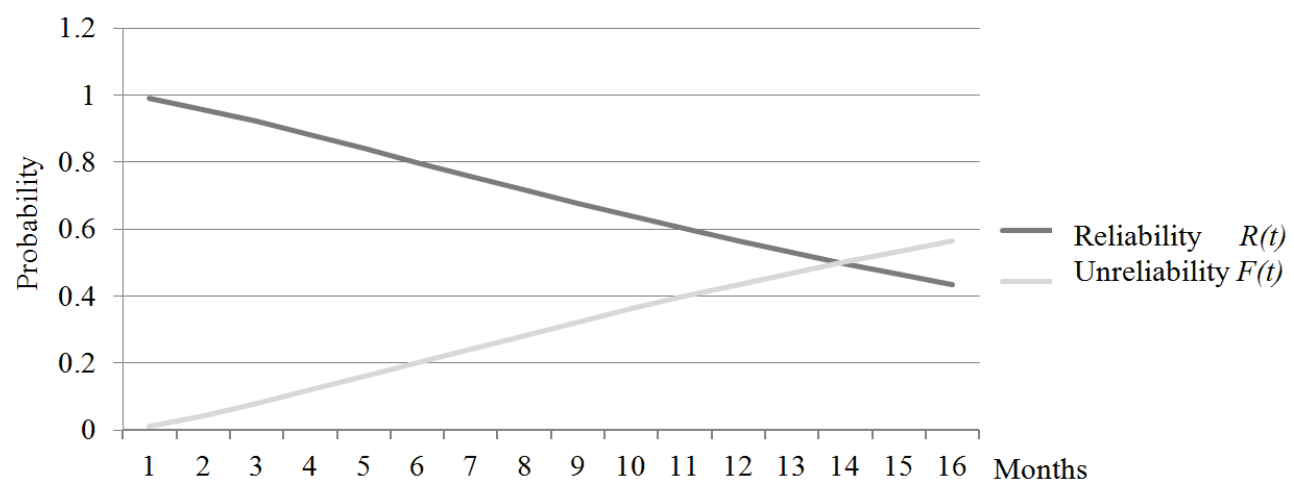

Figure 10 Graphical representation of the reliability/unreliability function after implementation of investment activities 


\section{CONCLUSION}

The results of operational readiness and reliability research give a clear picture of the extent to which implemented investment activities have increased the overall effectiveness of the real industrial system.

The reduction in the total number of hours of failure of the production system (from 403.85 hours to 219.8 hours for the same observed period), which can be directly linked to the failure of system components which were the subject of investment, can be emphasized as the main result of implementation of the model of influence and realization of investment activities. The analysis of obtained results confirms a positive trend of significant increase in operational readiness. The trend of the increase of operational readiness shows the increase of probability that the real system is in good working order under normal working conditions. The result of the increase of operational readiness had also a great impact on increasing the reliability of the production system. The increase of the reliability from 6 to 14 months means that the real system retains the necessary operating characteristics for a longer period of time by applying the corrective measures.

The positive trend of increasing the effectiveness of key parameters of the real industrial system is a confirmation that the investments in the production process and maintenance system have met planned expectations.

\section{REFERENCE}

[1] Highfill, G. S. \& Halverson L. A. (2006). Lowering total cost of ownership with breakthrough magnetic torque transfer technology. Cement Industry Technical Conference / Phoenix, 217-232. https://doi.org/10.1109/CITCON.2006.1635720

[2] Liu, H. N., Zhang, D. W., \& Wang, Z. (2009). Reliability calculation model of gears considering strength degradation. Industrial Engineering and Engineering Management / Beijing, 1195-1199.

[3] Jurjević M., Jurjević N., \& Koboević N. (2012). Modelling of dynamic reliability stages of a ship propulsion system with safety and exhaust emission. Technical Gazette, 19(1), 159-165.

[4] Papić, Lj. \& Milovanović, Z. (2007). Maintenance and reliability of technical systems, DQM Prijevor.

[5] Kuzle, I., Pandžić, H., \& Brezovec, M. (2010). Hydro generating units maintenance scheduling using Benders decomposition. Tehnički vjesnik, 17(2), 145-152.

[6] Bulatović M. (2008). Maintenance and effectiveness of technical systems, University of Montenegro - Faculty of Mechanical Engineering.

[7] Bojanić, B., Kondić, V., Gotal, M. (2014). Contribution to the reliability costs analysis. Technical journal, 8(1), 76-83.

[8] Milovanović, Z. (2003). Optimization of power plant reliability, University of Banja Luka - Faculty of Mechanical Engineering.

[9] Zeljković, V. (2001). Reliability testing, Lola institut, Beograd.

\section{Contact information:}

Dejan BRANKOVIĆ, M.Sc. maintenance manager SHP Celex, a.d. Banja Luka

Valjka Mladjenovića bb

78000 Banja Luka, Bosnia and Herzegovina

dejan.brankovic@shpgroup.eu

\section{Zdravko N. MILOVANOVIĆ, PhD, Full Professor}

University of Banja Luka, Faculty of Mechanical Engineering

Stepe Stepanovica 71,

78000 Banja Luka, Bosnia and Herzegovina

zdravko.milovanovic@mf.unibl.org

Stevo BOROJEVIĆ, PhD, Assistant Professor

University of Banja Luka, Faculty of Mechanical Engineering

Stepe Stepanovica 71 ,

78000 Banja Luka, Bosnia and Herzegovina

stevo.borojevic@mf.unibl.org 